\title{
Increased in vivo phosphorylation of insulin receptor at serine 994 in the liver of obese insulin-resistant Zucker rats
}

\author{
Marcelo P Coba, Marina C Muñoz, Fernando P Dominici, \\ Jorge E Toblli ${ }^{1}$, Clara Peña, Andrzej Bartke ${ }^{2}$ and Daniel Turyn \\ Instituto de Química y Fisicoquímica Biológicas (UBA-CONICET), Facultad de Farmacia y Bioquímica, Junín 956, C1113 AAD, Buenos Aires, Argentina \\ ${ }^{1}$ Laboratory of Experimental Medicine, Hospital Alemán, Buenos Aires, Argentina \\ ${ }^{2}$ Department of Physiology, School of Medicine, Southern Illinois University, Springfield, IL, 62794, USA \\ (Requests for offprints should be addressed to D Turyn; Email: dturyn@qb.ffyb.uba.ar)
}

\begin{abstract}
Serine phosphorylation of the insulin receptor (IR) has been proposed to exert an inhibitory influence on its tyrosine kinase activity. Previous works using site-directed mutagenesis suggested that serine 994 of the IR (IR Ser 994) might be part of an inhibitory domain of the receptor. In this study we examined whether this residue is subjected to phosphorylation in vivo. We used a sitephosphospecific antibody to determine the extent of phosphorylation of IR Ser 994 in insulin target tissues from two animal models of insulin resistance with different IR kinase (IRK) activity: obese (fa/fa) Zucker rats and transgenic mice overexpressing bovine growth hormone (PEPCK-bGH mice).

Phosphorylation at IR Ser 994 was markedly increased in liver of obese rats. This alteration appeared to be
\end{abstract}

tissue-selective since no phosphorylation on Ser 994 was detected in IRs isolated from skeletal muscle of these animals. On the other hand, the phosphorylation level of IR Ser 994 was very low in liver of PEPCK-bGH mice and did not differ from that of the control group. We have also demonstrated that protein kinase (PK) C isoforms $\alpha$, $\beta \mathrm{I}$ and $\zeta$ are able to promote the in vitro phosphorylation of the IR on Ser 994. Differential findings in these two models of insulin resistance might thus reflect increased PKC activity resulting from increased lipid availability in obese Zucker rats. Our results suggest that Ser 994 is a novel in vivo IR phosphorylation site that might be involved in the regulation of the IRK in some states of insulin resistance.

Journal of Endocrinology (2004) 182, 433-444

\section{Introduction}

The insulin receptor (IR) is a tetrameric protein composed of two extracellular $\alpha$ - subunits and two transmembrane $\beta$-subunits linked by disulfide bonds (White \& Kahn 1994). Binding of insulin to the $\alpha$-subunits of the IR induces rapid phosphorylation of the IR $\beta$-subunit in tyrosine residues and activation of its intrinsic tyrosine kinase activity (White \& Kahn 1994, Saltiel \& Kahn 2001). In particular, the phosphorylation of three tyrosine residues in the kinase domain results in maximum tyrosine kinase activity (White \& Kahn 1994, Saltiel \& Kahn 2001), and enables the subsequent phosphorylation of several endogenous proteins. These events are essential for further signal transduction and consequently for insulin action (Saltiel \& Kahn 2001). In addition to tyrosine, the IR undergoes serine and threonine (Ser/Thr) phosphorylation, which is detected in the basal state and in response to stimulation of cells by phorbol esters (Takayama et al. 1984, Bollag et al. 1986), cAMP analogues (Stadtmauer \& Rosen 1986), and insulin itself
(Kasuga et al. 1982, Häring et al. 1984, Pillay et al. 1991). Although the functional significance of this phosphorylation is not completely understood, results from in vitro studies indicate that it may attenuate signaling by decreasing insulin-stimulated tyrosine phosphorylation (Takayama et al. 1984, Bollag et al. 1986, Takayama et al. 1988). This mechanism may also regulate insulin action in vivo. Insulin resistance of polycystic ovary syndrome, gestational diabetes mellitus, and obesity appears to be associated with excessive Ser/Thr phosphorylation of the IR in skeletal muscle (Dunaif 1997, Itani et al. 2000, Shao et al. 2000). Increased Ser/Thr phosphorylation was demonstrated to be linked to reduced IR kinase (IRK) activity in liver of fasted rats (Karasik et al. 1990) and in skeletal muscle of obese ( $f a / f a)$ Zucker rats (Zhou et al. 1999). Among the serine kinases that might be involved in IR inhibition, protein kinase $\mathrm{C}$ (PKC) is one candidate with potential pathophysiological relevance. Increased PKC activity is associated with impaired insulinstimulated IRK activity (Takayama et al. 1988, Karasik et al. 1990, Chin et al. 1994, Itani et al. 2000). Moreover, 
the amount of membrane-associated PKC is increased in livers of obese insulin-resistant Zucker rats and in obese patients with non-insulin dependent diabetes mellitus, suggesting that excessive PKC activity may contribute to some states of insulin resistance (Considine et al. 1995, Qu et al. 1999).

Several serine residues in the IR $\beta$-subunit have been identified as phosphorylation sites. According to the numbering system of Ullrich et al. (1985), these include residues 955/56 (Feener et al. 1993, Liu F \& Roth 1994a), 1023/25 (Liu F \& Roth RA 1994b), 1293/94 (Lewis et al. 1990a, Tavare et al. 1991), 1309 (Al-Hasani et al. 1997), 1315 (Coghlan et al. 1994, Feener et al. 1994) and 1177/78/82 (Bossenmaier et al. 2000). In addition, Thr 1336 of the IR was identified as a major target for phosphorylation by PKC (Lewis et al. 1990b). However, no relationship between the level of phosphorylation of these sites and the activation state of the IRK has been established (Anderson \& Olefsky 1991, Tavare et al. 1991, Coghlan et al. 1994, Kellerer et al. 1995, Strack et al. 1997).

Insulin receptor Ser 994 has been identified as a potential inhibitory site of the IRK as determined by site-directed mutagenesis (Strack et al. 1997). This site appears to be important for mediating IRK inhibition by PKC (Strack et al. 2000).

Recently, we obtained a polyclonal antibody that specifically recognizes phospho-Ser 994 (Coba et al. 2003). By making use of this site-specific anti-phosphopeptide antibody, in the current work we have assessed the extent of phosphorylation of the IR on Ser 994 in insulin-target tissues from two animal models of insulin resistance: the Zucker fatty rat $(f a / f a)$, a model of genetic obesity with severe hyperinsulinemia characterized by reduced insulinstimulated IRK activity in liver and muscle (Hurrell et al. 1989, Kasiske et al. 1992, Zhou et al. 1999) and the PEPCK-bGH mouse, a model of growth hormoneinduced insulin resistance characterized by increased basal levels of IRK activity in liver and muscle (Valera et al.1993, Balbis et al. 1996, Dominici et al. 1998). As an indication of the activation status of the IRK, the in vivo level of IR tyrosine phosphorylation was monitored in parallel with the levels of phospho-Ser 994 and phospho-Thr 1336 in these models.

\section{Materials and Methods}

\section{Materials}

HEPES, Tris, phenylmethylsulfonyl fluoride (PMSF), aprotinin, leupeptin, ATP, Triton X-100, Tween 20, phosphatase acid Type IV- from potato, Protein A-Sepharose $6 \mathrm{MB}$, porcine insulin, bovine serum albumin, nitrocellulose membranes, and wheat germ agglutinin (WGA)-Sepharose were from Sigma Chemical Co. Affigel-10 and the reagents and apparatus for SDS-PAGE and immunoblotting were obtained from Bio-Rad. ${ }^{125}$ I-protein A was purchased from ICN Biomedicals.

\section{Antibodies}

The monoclonal anti-phosphotyrosine (anti-PY, PY99) and the polyclonal anti-insulin receptor $\beta$-subunit antibody (anti-IR, C-19) were purchased from Santa Cruz Biotechnology, Inc. Rabbit polyclonal antiserum raised against synthetic phosphopeptides containing Thr 1336 of the IR (anti-PT1336) was a generous gift of Dr MP Coghlan and was prepared as previously described (Coghlan et al. 1994). The polyclonal antibody against phospho-Ser 994 of the IR (anti-PS994) was obtained by immunization of the rabbits with the phopsphorylated peptide LRELGQGSFGMVYE, as previously described (Coba et al. 2003).

\section{Animals}

Male obese Zucker rats $(f a / f a)$ and their age-matched lean controls $(+/$ ?) were purchased from Charles River Laboratories and were used at the age of $4-5$ months. Male transgenic mice overexpressing bovine growth hormone (bGH) were originally produced by a microinjection of the $\mathrm{bGH}$ gene fused to the control sequences of the rat phosphenolpyruvate carboxykinase gene into the pronuclei of fertilized mouse eggs (Valera et al. 1993). The hemizygous transgenic mice used in the present study were derived from a founder male with $\sim 25$ copies of the hybrid gene and were produced by mating transgenic males with normal C57BL/6 X C3H F1 hybrid females. These matings produced approximately equal numbers of transgenic mice and normal animals that were used as controls. Transgenic mice had markedly accelerated postweaning growth, leading to a significant increase in body weight at the age of 3-5 months when these studies were conducted.

All animals were housed three to five per cage in a room with controlled light (12:12-h light-dark cycle) and temperature $\left(22 \pm 2{ }^{\circ} \mathrm{C}\right)$ with free access to water and standard chow. All animal studies were performed following the 'Principles of laboratory animal care' (NIH publication no. 85-23, revised 1985).

\section{Measurement of glucose, insulin and triglycerides concentrations}

Fasting serum insulin concentration was determined using a solid phase radioimmunoassay kit from Diagnostic Products Inc. Measurements were performed in duplicate and variations between duplicate samples of less than $5 \%$ were considered acceptable. The sensitivity of the assays was $3 \mu \mathrm{IU} / \mathrm{ml}$. Serum glucose was measured with 
the glucose oxidase procedure (Trender; Sigma). Serum triglycerides were estimated using a colorimetric assay [triglyceride (INT), procedure 336; Sigma).

\section{Experimental design and preparation of tissue extracts}

Animals were fasted overnight and $15 \mathrm{~min}$ before the experiment they were killed by the intraperitoneal administration of $100 \mathrm{mg}$ of sodium pentobarbital per $\mathrm{kg}$ body weight. After anesthesia was induced, the portal vein was exposed and $10 \mathrm{IU}$ insulin per $\mathrm{kg}$ body weight in normal saline $(0.9 \% \mathrm{NaCl})$ were injected in a final volume of $0.1 \mathrm{ml}$. Additional animals were injected with diluent to obtain data under basal conditions. The liver and the rectus abdominus muscle were removed $50 \mathrm{~s}$ and 2 min after injection respectively, frozen under dry ice and kept at $-70{ }^{\circ} \mathrm{C}$ until further use. Tissues were minced coarsely and homogenized with a polytron homogenizer in 10 volumes of ice-cold lysis buffer containing 1\% Triton $\mathrm{X}-100,50 \mathrm{mM}$ HEPES (pH 7.4), $100 \mathrm{mM} \mathrm{Na}_{4} \mathrm{P}_{2} \mathrm{O}_{7}$, $100 \mathrm{mM} \mathrm{NaF}, 10 \mathrm{mM}$ EDTA, $10 \mathrm{mM} \mathrm{Na}_{3} \mathrm{VO}_{4}, 2 \mathrm{mM}$ PMSF and $10 \mu \mathrm{g} / \mathrm{ml}$ aprotinin. Tissue extracts were centrifuged at $100000 \times \mathbf{g}$ for $1 \mathrm{~h}$ at $4{ }^{\circ} \mathrm{C}$ to remove insoluble material; protein concentration was measured using the Bradford method (Bradford 1976).

\section{Immunoprecipitation}

Supernatants containing equal amounts of protein $(8-16 \mathrm{mg})$ were incubated overnight at $4{ }^{\circ} \mathrm{C}$ with anti-IR $(4 \mu \mathrm{g} / \mathrm{ml})$. Immune complexes were collected by incubation with protein A-Sepharose $6 \mathrm{MB}$ for $2 \mathrm{~h}$ at $4{ }^{\circ} \mathrm{C}$, washed three times with $50 \mathrm{mM}$ Tris buffer $(\mathrm{pH} \mathrm{7 \cdot 4)}$ containing 1\% Triton X-100 and $1 \mathrm{mM} \mathrm{Na} \mathrm{VO}_{4}$, boiled in Laemmli sample buffer, and stored at $-70{ }^{\circ} \mathrm{C}$ until needed for electrophoresis.

\section{Immunoblotting}

Immunoprecipitated proteins were resolved by SDSpolyacrylamide gel electrophoresis $(7 \cdot 5 \%$ acrylamide) in a Bio-Rad miniature slab gel apparatus. Electrotransfer of proteins from the gel to nitrocellulose membranes was performed for $1 \mathrm{~h}$ at $100 \mathrm{~V}$ (constant) using the Bio-Rad miniature transfer apparatus in $25 \mathrm{mM}$ Tris, $192 \mathrm{mM}$ glycine and $20 \%(\mathrm{v} / \mathrm{v})$ methanol. To reduce non-specific binding, the nitrocellulose membranes were incubated for $2 \mathrm{~h}$ with T-TBS buffer $(50 \mathrm{mM}$ Tris- $\mathrm{HCl}, \mathrm{pH} 7 \cdot 6$, $150 \mathrm{mM} \mathrm{NaCl}$, and $0.02 \%$ Tween 20) containing 3\% BSA. Blots were then incubated overnight with anti-PY $(1 \mu \mathrm{g} / \mathrm{ml})$ to detect tyrosine phosphorylation of IR, with anti-PT1336 (1/1000) to detect IR phosphorylation on threonine 1336 or with anti-PS994 $(1 / 250)$ to detect IR phosphorylation on serine 994 . The membranes were subjected to four 5 min washes in T-TBS buffer and were then incubated with ${ }^{125}$ I-protein A in T-TBS containing $3 \% \mathrm{BSA}$ for $1 \mathrm{~h}$ at room temperature and then washed again for 60 min as described above. ${ }^{125}$ I-protein A bound to antibodies was detected by autoradiography and band intensities were quantified by densitometry.

\section{Insulin receptor purification}

Preparation of a microsomal fraction containing liver plasma membranes was performed using a previously described procedure (Dominici et al. 1998) with slight modifications. The preparation buffer was $50 \mathrm{mM}$ Tris$\mathrm{HCl}(\mathrm{pH} 7 \cdot 6$ ), 0.25 $\mathrm{M}$ sucrose, $1 \mathrm{mM}$ PMSF and $0.5 \%$ aprotinin, plus $30 \mathrm{mM} \mathrm{Na} \mathrm{P}_{2} \mathrm{O}_{7}, 1 \mathrm{mM} \mathrm{Na} \mathrm{NO}_{4}$ and $10 \mathrm{mM} \mathrm{NaF}$ as phosphatase inhibitors. The resulting membrane pellet was resuspended in solubilization buffer (50 mM Tris- $\mathrm{HCl}$ pH 7·6, 1\% Triton X-100, $1 \mathrm{mM}$ PMSF, $0.5 \%$ aprotinin, $30 \mathrm{mM} \mathrm{Na}_{4} \mathrm{P}_{2} \mathrm{O}_{7}, 1 \mathrm{mM} \mathrm{Na}_{3} \mathrm{VO}_{4}$ and $10 \mathrm{mM} \mathrm{NaF}$ ), incubated with gentle agitation for $1 \mathrm{~h}$ at $4{ }^{\circ} \mathrm{C}$, and centrifuged for $90 \mathrm{~min}$ at $100000 \times \mathrm{g}$. The supernatant (solubilized receptor) was loaded onto a column containing WGA-Sepharose and mixed end over end for $16 \mathrm{~h}$ at $4{ }^{\circ} \mathrm{C}$ for affinity chromatography purification. The column was washed with 30 volumes of buffer (50 mM HEPES, $\mathrm{pH} 7 \cdot 6,0 \cdot 15 \mathrm{M} \mathrm{NaCl}, 0 \cdot 1 \%$ Triton $\mathrm{X}-100,30 \mathrm{mM} \mathrm{Na}{ }_{4} \mathrm{P}_{2} \mathrm{O}_{7}, 1 \mathrm{mM} \mathrm{Na} \mathrm{VO}_{4}$ and $10 \mathrm{mM}$ $\mathrm{NaF})$. Bound receptors were eluted with buffer containing $50 \mathrm{mM}$ HEPES, (pH 7.6), $0.15 \mathrm{M} \mathrm{NaCl}, 0 \cdot 1 \%$ Triton $\mathrm{X}-100$ and $0.3 \mathrm{M} \mathrm{N}$-acetyl glucosamine. The phosphatase inhibitors were omitted in the preparation when the purification of the IR was to be followed by treatment with acid phosphatase.

\section{Treatment of purified IRs with acid phosphatase}

Acid phosphatase type IV from potato $(8 \mathrm{mg})$ in $50 \mathrm{mM}$ HEPES buffer, $(\mathrm{pH} 6 \cdot 0)$, was incubated overnight at $4{ }^{\circ} \mathrm{C}$ with $2 \mathrm{ml}$ of Affi-gel 10 (Bio-Rad). The protein-coupled resin was then washed with $100 \mathrm{ml}$ ice cold water, incubated for $90 \mathrm{~min}$ at $4{ }^{\circ} \mathrm{C}$ with $1 \mathrm{M}$ ethanolamine $(\mathrm{pH} 8 \cdot 0)$ to block unreacted amino groups and then washed and equilibrated with $50 \mathrm{mM}$ HEPES (pH 5.0). Affinity-purified IRs from liver of obese Zucker $(\mathrm{fa} / \mathrm{fa}$ ) rats were incubated for $4 \mathrm{~h}$ at $25^{\circ} \mathrm{C}$ with 500 units of the immobilized enzyme in $50 \mathrm{mM}$ HEPES, ( $\mathrm{pH} 5 \cdot 0$ ). Dephosphorylated samples were centrifuged, and $500 \mu \mathrm{l}$ of supernatants were immunoprecipitated with anti-IR in $50 \mathrm{mM}$ HEPES buffer, ( $\mathrm{pH} 7 \cdot 6$ ), 1\% Triton X-100, $2 \mathrm{mM}$ PMSF and $1 \mu \mathrm{g} / \mathrm{ml}$ aprotinin. Control samples were prepared by treating IRs that had been isolated in conditions that preserved basal phosphorylation, with immobilized acid phosphatase that had been formerly inactivated by boiling for $1 \mathrm{~h}$. The resulting samples were then subjected to immunoprecipitation with anti-IR in buffer $50 \mathrm{mM}$ HEPES, (pH 7·6), 1\% Triton X-100, 
Table 1 Metabolic parameters of obese Zucker rats and their aged-matched lean controls

\begin{tabular}{|c|c|c|}
\hline & Lean $(+/ ?)$ & Obese $(f a / f a)$ \\
\hline Number of animals & 13 & 13 \\
\hline Body weight (g) & $330 \pm 26$ & $604 \pm 24^{*}$ \\
\hline Glucose $(\mathrm{mg} / \mathrm{dl})$ & $99 \pm 10$ & $255 \pm 22^{*}$ \\
\hline Insulin $(\mu \mathrm{IU} / \mathrm{ml})$ & $8 \pm 2$ & $102 \pm 19^{*}$ \\
\hline Triglycerides $(\mathrm{mg} / \mathrm{dl})$ & $39 \pm 9$ & $940 \pm 139 *$ \\
\hline
\end{tabular}

Values are means \pm S.E. Blood glucose, insulin and triglyceride concentrations were measured after an overnight fast. *Significantly different from lean rats $(P<0 \cdot 001)$.

$100 \mathrm{mM} \quad \mathrm{Na}_{4} \mathrm{P}_{2} \mathrm{O}_{7}, 100 \mathrm{mM} \quad \mathrm{NaF}, 10 \mathrm{mM}$ EDTA, $10 \mathrm{mM} \mathrm{Na} \mathrm{VO}_{4}, 2 \mathrm{mM}$ PMSF and $10 \mu \mathrm{g} / \mathrm{ml}$ aprotinin. Immune complexes were collected with protein A-Sepharose $6 \mathrm{MB}$, eluted by boiling with Laemmli buffer for $5 \mathrm{~min}$ and kept at $-70{ }^{\circ} \mathrm{C}$ until electrophoresis.

In vitro phosphorylation of purified IRs by PKC isoforms

IRs isolated from liver of lean rats were subjected to dephosphorylation by incubation with immobilized acid phosphatase as described above and then incubated with $0 \cdot 2$ units of different PKC isoforms $(\alpha, \beta \mathrm{I}, \beta \mathrm{II}, \delta, \varepsilon, \gamma, \zeta$ and $\eta$ ) in independent experiments. The incubation was performed in the absence or presence of $7 \mu \mathrm{g} / \mathrm{ml}$ phosphatidylserine, $2 \mu \mathrm{M}$ diolein and $1.5 \mathrm{mM} \mathrm{CaCl}_{2}$ in a reaction mixture containing $1 \mathrm{mM}$ EGTA, $10 \mathrm{mM}$ $\mathrm{MgCl}_{2}, 3 \mathrm{mM} \mathrm{MnCl}, 15 \mathrm{mM}$ Tris, (pH 7.4) and $50 \mu \mathrm{M}$ ATP. After $3 \mathrm{~h}$ at $22{ }^{\circ} \mathrm{C}$, the reaction was terminated by the addition of $900 \mu \mathrm{l} 50 \mathrm{mM}$ Tris buffer, $(\mathrm{pH} \mathrm{7 \cdot 4),1 \%}$ Triton X-100, $2 \mathrm{mM}$ PMSF, $1 \mu \mathrm{g} / \mathrm{ml}$ aprotinin, $10 \mathrm{mM}$ EDTA, $100 \mathrm{mM} \mathrm{Na} \mathrm{P}_{2} \mathrm{O}_{7}, 100 \mathrm{mM} \mathrm{NaF}$ and $\mathrm{Na}_{3} \mathrm{VO}_{4}$ and the IR was immunoprecipitated by incubation with anti-IR and protein A-Sepharose as described above.

\section{Statistical analysis}

Results are presented as means \pm S.E.M. Experiments were performed by analyzing all groups of animals in parallel. Data were analyzed with ANOVA followed by the Tukey-Kramer test. Student's t-test was used when the values of two groups were analyzed. $P$ values less than $0 \cdot 05$ were considered significant.

\section{Results}

\section{Animal characteristics}

Data describing the metabolic parameters of the two animals model used are presented in Tables 1 and 2. A state of severe insulin resistance was evident in obese Zucker rats. Fasting glucose levels were increased by $2 \cdot 6$-fold in the obese rats $(P<0 \cdot 001)$, whereas insulin levels
Table 2 Metabolic parameters of PEPCK-bGH transgenic mice and their aged-matched controls

\begin{tabular}{|c|c|c|}
\hline & Normal & Transgenic \\
\hline Number of animals & 10 & 10 \\
\hline Body weight (g) & $28 \pm 4$ & $52 \pm 11^{*}$ \\
\hline Glucose $(\mathrm{mg} / \mathrm{dl})$ & $146 \pm 23$ & $128 \pm 24$ \\
\hline Insulin $(\mu \mathrm{IU} / \mathrm{ml})$ & $12 \pm 5$ & $102 \pm 23^{*}$ \\
\hline
\end{tabular}

Values are means \pm S.E. Blood glucose and insulin concentrations were measured after an overnight fast. *Significantly different from normal mice $(P<0 \cdot 001)$.

were increased by $12 \cdot 7$-fold $(P<0 \cdot 001)$ relative to lean controls (Table 1). In addition, when compared with the lean control animals, obese rats displayed a large increase in serum triglyceride concentrations $(24 \cdot 1$-fold increase; $P<0 \cdot 001$; Table 1). PEPCK-bGH transgenic mice displayed a state of insulin resistance, shown by the concomitant presence of normal fasting glucose levels and substantially elevated plasma insulin concentration (8.5-fold above control values; $P<0 \cdot 001$; Table 2 ).

IR tyrosine, Ser 994, and Thr 1336 phosphorylation in liver of lean and obese Zucker rats.

In control lean rats, insulin increased IR tyrosine phosphorylation 6-fold in liver (Fig. 1A and B). Although insulin stimulation led to an increase of IR tyrosine phosphorylation in liver of obese rats, the phosphorylation level attained was 60\% lower than that observed for insulin-stimulated control animals $(n=5 ; \quad P<0 \cdot 05)$, (Fig. 1A and B). Basal IR Ser 994 phosphorylation was very low in liver of lean Zucker rats (Fig. 1C and D). In contrast, phospho-Ser 994 levels were increased by approximately 25 -fold in IRs isolated from obese rats liver $(n=8 ; P<0 \cdot 05)$ relative to lean rats (Fig. $1 \mathrm{C}$ and D). In liver from lean rats, insulin administration failed to stimulate the phosphorylation of the IR at Ser 994, while in liver of obese rats, the same treatment resulted in a $56 \%$ decrease in the levels of phosphorylation of this residue $(n=8 ; P<0.05$ vs saline-injected obese rats) (Fig. $1 \mathrm{C}$ and D). IR levels were similar in liver of lean and obese Zucker rats (Fig. 1C and D). Basal IR Thr 1336 phosphorylation levels were similar in liver of lean and obese rats (Fig. 1E and F). Insulin increased IR Thr1336 phosphorylation $7 \cdot 1$-fold in liver of lean rats (Fig $1 \mathrm{E}$ and F). In liver of obese rats, although phospho-Thr 1336 levels increased after insulin stimulation, the extent of phosphorylation at this site was $60 \%$ lower than that observed in insulin-stimulated lean rats $(n=8 ; P<0 \cdot 05)$.

IR tyrosine, Ser 994, and Thr 1336 phosphorylation in skeletal muscle of lean and obese Zucker rats

In control lean rats, insulin increased IR tyrosine phosphorylation $4 \cdot 5$-fold in skeletal muscle (Fig. 2A and B), 
A

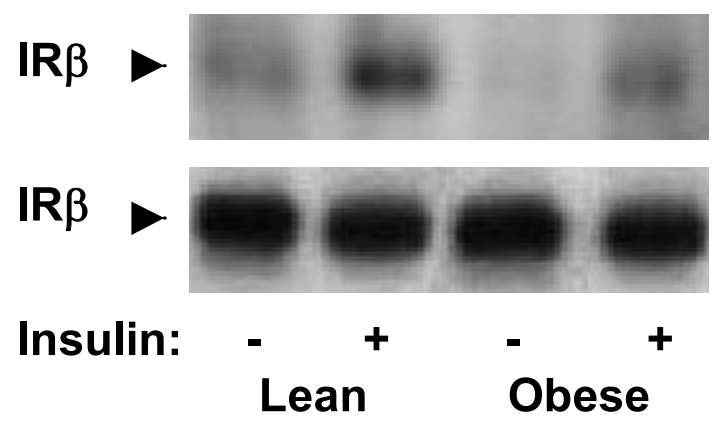

C

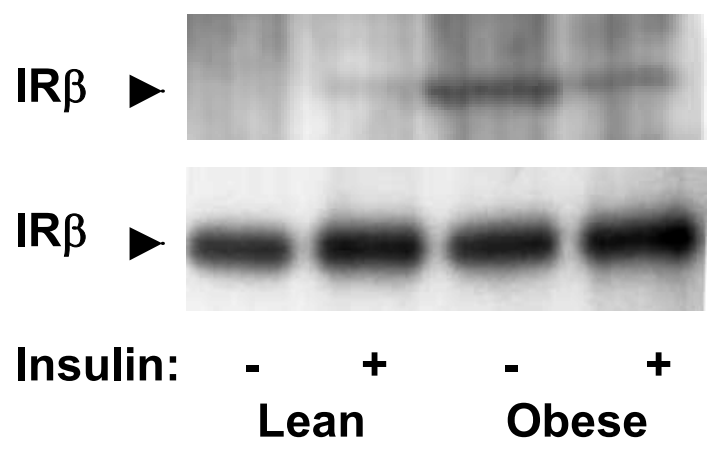

E

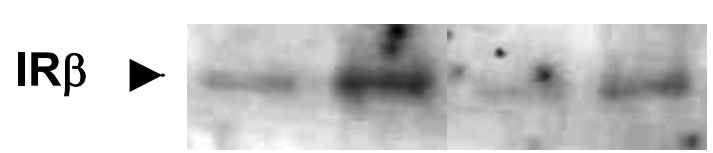

IR $\beta$

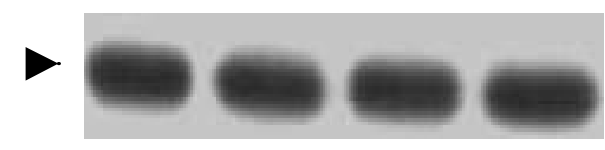

Insulin:

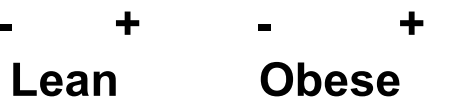

B

\section{anti-PY}

anti-IR

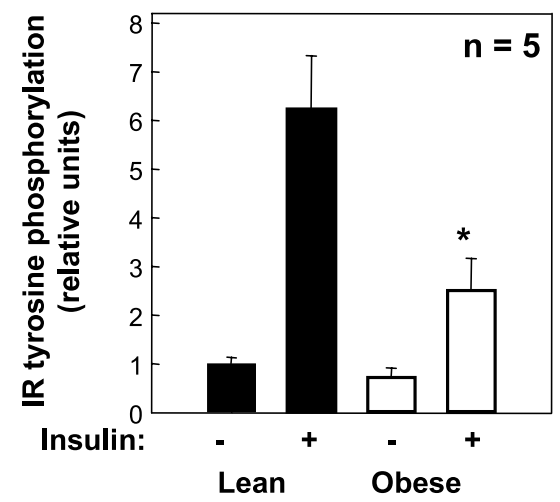

D

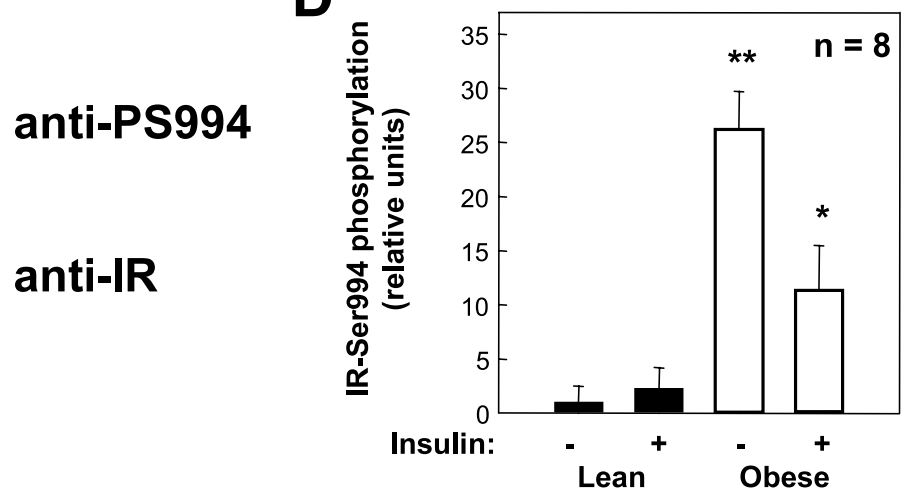

F

\section{anti-PT1336}

anti-IR

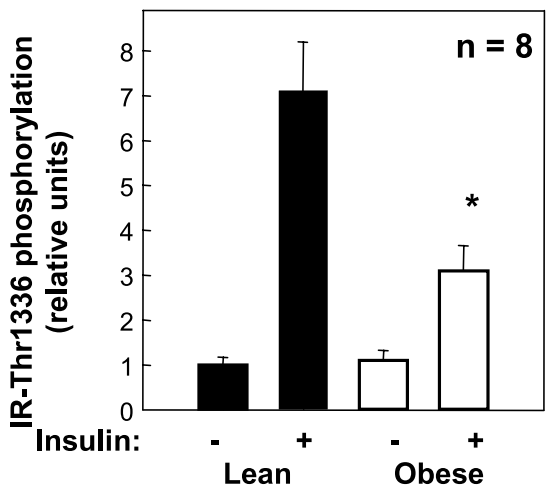

Figure 1 Phosphorylation status of the IR in liver of lean and obese Zucker rats. Animals were injected with saline (-) or 10 IU insulin (+) per kg/body weight. Equal amounts of solubilized liver proteins obtained as described in Materials and Methods were immunoprecipitated with an anti-IR antibody (anti-IR), separated by SDS-PAGE and immunoblotted either with an anti-phosphotyrosine antibody (anti-PY) (A, upper panel), with an antibody that recognizes the IR phosphorylated on Ser 994 (anti-PS994) (C, upper panel) or with an antibody that recognizes the IR phosphorylated on Thr1336 (anti-PT1336) (E, upper panel). Membranes were stripped and reblotted with anti-IR (A, C, and E, lower panels); IR $\beta$, IR $\beta$-subunit. B, D and F, data quantification by densitometric analysis. Values are expressed as relative to control assigning a value of 1 to the mean of saline-injected normal rats. Each bar represents mean \pm S.E.M. of the indicated number of independent experiments. ${ }^{*} P<0 \cdot 05$ vs the corresponding insulin-stimulated lean value. ${ }^{*} P<0 \cdot 001$ vs saline-injected lean. 

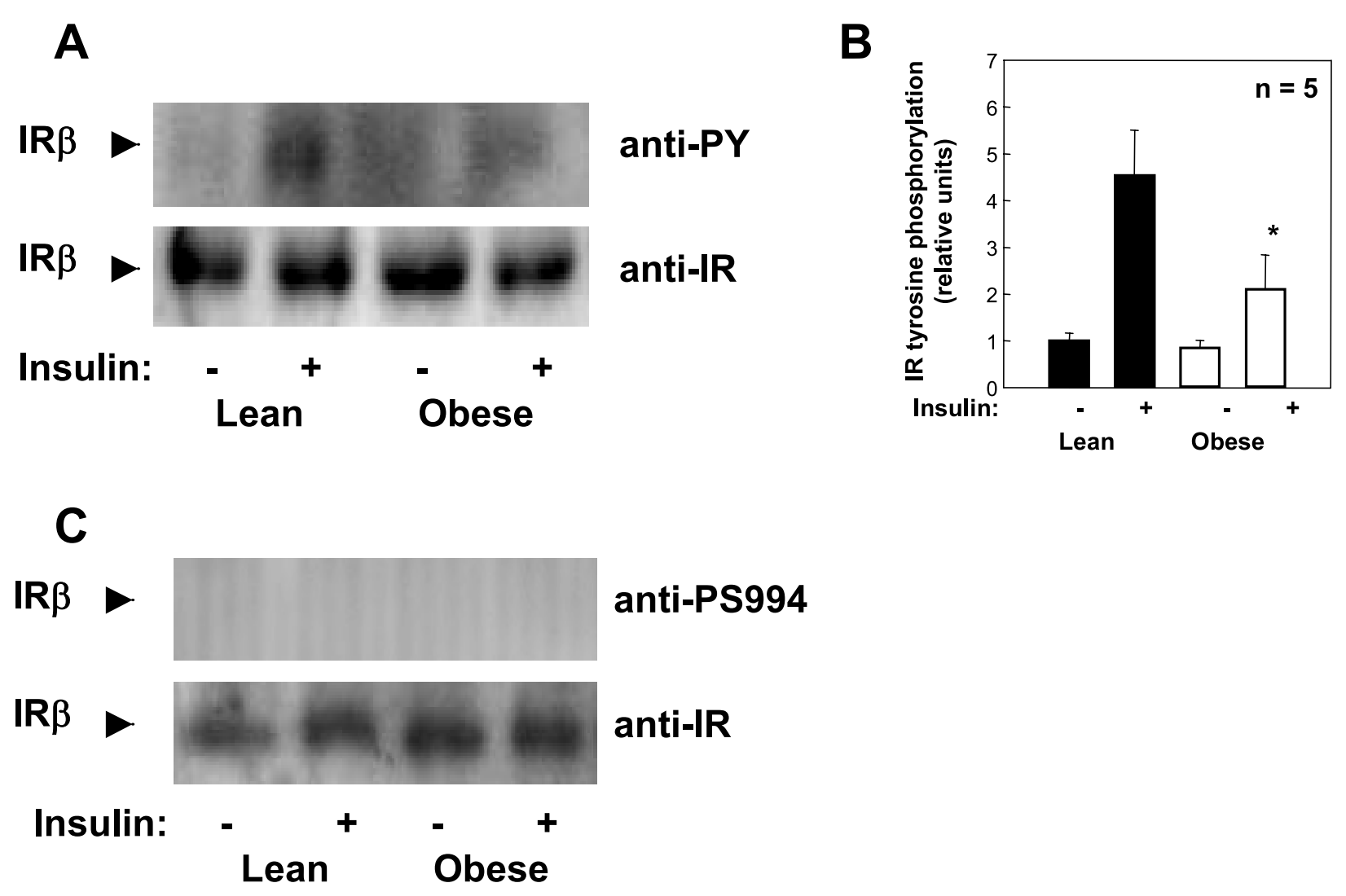

\section{anti-PS994}

\section{anti-IR}
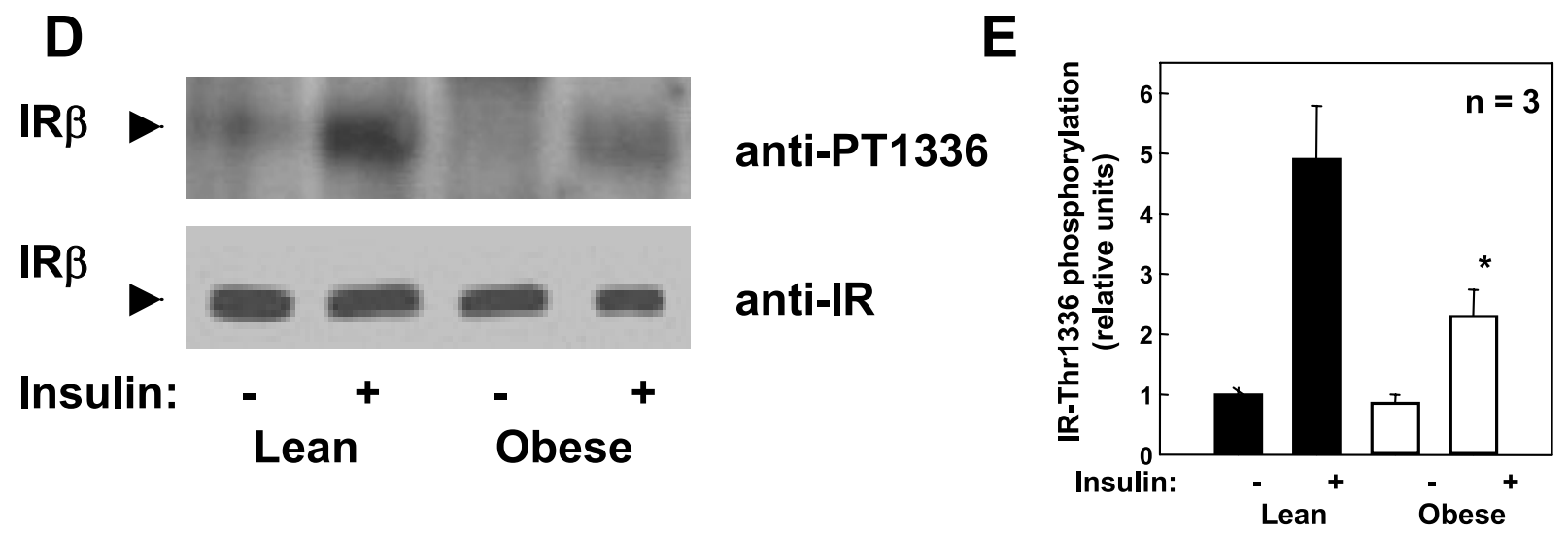

Figure 2 Phosphorylation status of the IR in skeletal muscle of lean and obese Zucker rats. Animals were injected as described in Fig. 1. Equal amounts of solubilized muscle proteins obtained as described in Materials and Methods were immunoprecipitated with an anti-IR antibody (anti-IR), separated by SDS-PAGE and immunoblotted with either an anti-phosphotyrosine antibody (anti-PY) (A, upper panel), with anti-PS994 (C, upper panel) or with anti-PT1336 (D, upper panel). Membranes were stripped and reblotted with anti-IR (A, C, and D, lower panels); IR $\beta$, IR $\beta$-subunit. B and $\mathrm{E}$, data quantification by densitometric analysis. Values are expressed as relative to control assigning a value of 1 to the corresponding mean of saline-injected normal rats. Each bar represents mean \pm S.E.M. of the indicated number of independent experiments. ${ }^{*} P<0 \cdot 05$ vs the corresponding insulin-injected lean value.

while in skeletal muscle of obese rats insulin-stimulated IR tyrosine phosphorylation was reduced by $56 \%(n=5$; $P<0 \cdot 05)$ relative to the insulin-stimulated lean value (Fig. 2A and B). The extent of phosphorylation of the IR on Ser 994 was analyzed in rectus abdominus muscle from obese and lean rats. Basal IR Ser 994 phosphorylation could not be detected in any of the samples analyzed $(n=8$; Fig. 2C). In an attempt to increase the sensitivity of the 
assay, the amount of protein used for the inmunoprecipitation step was increased from 8 to $16 \mathrm{mg}$ ). In addition, a different detection method was tried. Enhanced chemiluminescence was used instead of ${ }^{125}$ I-protein A. In spite of these modification, Ser 994 phosphorylation was not detected in skeletal muscle (data not shown).

IR levels in muscle were similar in lean and obese rats $(n=8$; Fig $2 \mathrm{C})$. Similar results were found in samples from tensor fasia latae and gastrocnemius muscle obtained from both groups of animals (data not shown). The extent of IR Thr 1336 phosphorylation in skeletal muscle under basal conditions was very low in both groups of animals (Fig. 2D and E). In skeletal muscle of lean rats, insulin increased IR Thr 1336 phosphorylation by 4.9-fold, while in skeletal muscle from obese rats insulin increased the phosphorylation of this site by only $2 \cdot 3$-fold $(n=3$; $P<0 \cdot 05$; Fig. 2D and E).

IR tyrosine, Ser 994, and Thr 1336 phosphorylation in liver of bovine growth hormone transgenic mice

Basal tyrosine phosphorylation of the IR increased $4 \cdot 5$-fold in liver of PEPCK-bGH transgenic mice $(n=3 ; P<0 \cdot 05)$, relative to control mice (Fig. $3 \mathrm{~A}$ and B). Insulin increased IR tyrosine phosphorylation by approximately 7-fold in liver of normal mice (Fig. 3A and B). In liver of PEPCK-bGH transgenic mice, insulin-stimulated levels of IR tyrosine phosphorylation were similar to those detected in insulin-treated control animals. (Fig. 3A and B). A very low anti-PS994 immunoreactivity was detected in IRs isolated from liver of PEPCK-bGH transgenic mice or the corresponding normal control mice with $(n=3$; Fig. 3C). Quantification by densitometric analysis of the signal obtained was not possible. In vivo insulin administration had no detectable effect on IR Ser 994 phosphorylation in liver from any of the mice analyzed (Fig. 3C). In contrast to the large increase in basal IR tyrosine phosphorylation exhibited by transgenic mice, basal IR Thr 1336 phosphorylation levels in liver of PEPCK-bGH mice were low and similar to those detected in liver of normal control mice $(n=3$; Fig. 3D and E). In liver of both groups of animals, insulin increased IR Thr 1336 phosphorylation to a similar extent (Fig. 3D and $\mathrm{E})$.

\section{Characterization of the phospho-Ser 994 antibody}

IRs purified from livers of obese Zucker rats were dephosphorylated by treatment with immobilized acid phosphatase and subjected to immunoblot analysis with anti-PS994. This treatment completely abolished the immunoreactiviy of the anti-PS994 antibody (Fig. 4, lane 1), while a strong signal was detected in control IR samples that had been treated with inactive immobilized acid phosphatase (Fig. 4, lane 2). Additional confirmation of the specificity of the anti-PS994 antibody was obtained when aliquots of extracts prepared from liver of obese Zucker rats were immunoprecipitated with anti-IR and immunoblotted with anti-PS994 in the presence of the phosphorylated peptide used as immunogen. The presence of the phosphorylated peptide containing PS994 in the incubation media prevented the immunoblotting of anti-PS994 (Fig. 4, lanes 3 and 4). In contrast, when the incubation with anti-PS994 was performed in the presence of either the same peptide sequence unphosphorylated or with a serine-phosphorylated nonrelated peptide sequence (VKTVNE(PS)ASLRERI) the immunoreactivity of anti-PS994 towards IR isolated from liver of obese Zucker rats remains unaltered (Fig. 4, lanes $5-8)$.

\section{Phosphorylation of IR Ser 994 by PKC isoforms}

To determine if Ser 994 of the IR is a target for phosphorylation by PKC, WGA-purified IRs from lean Zucker rats liver were subjected to dephosphorylation with immobilized acid phosphatase and incubated with PKC isoforms belonging to the three subclasses of PKC. Phospho-Ser 994 levels were then analyzed by subjecting the samples to immunoprecipitation with anti-IR followed by immunoblotting with anti-PS994. Out of eight PKC isoforms tested, only three were able to promote phosphorylation of the IR on Ser 994. They included PKC $\alpha$ and PKC $\beta \mathrm{I}$ (Fig. 5, left and centre) belonging to the classical or conventional class and $\mathrm{PKC} \zeta$ from the atypical class (Fig. 5, right). Incubation of IRs with PKC isoforms belonging to the novel group $(\delta, \varepsilon$ and $\eta)$ failed to induce phosphorylation of Ser 994 as detected by immunoblotting with anti-PS994 (Fig. 5, right). The highest level of IR phosphorylation on Ser 994 was attained after incubation with $\mathrm{PKC} \zeta$ (Fig. 5). To confirm that the negative result obtained by incubation with isoforms $\beta \mathrm{II}, \delta, \varepsilon, \gamma$ and $\eta$ was the consequence of a lack of induction of phosphorylation of the IR on Ser 994 instead of a defective activation of these enzymes, their activity was evaluated by incubation with a specific peptide substrate. All the isosymes of PKC were able to phosphorylate the substrate used (data not shown).

\section{Discussion}

Among the factors affecting the insulin-signaling pathway, phosphorylation of the IR and the IR substrates (IRSs) on serine residues, emerges as a potential cause of attenuation of the IRK leading to decreased insulin-stimulated tyrosine phosphorylation (Saltiel \& Kahn 2001). Although not completely characterized, this inhibitory phosphorylation may provide a negative feedback to insulin signaling and serve as a mechanism for crosstalk from other pathways (Saltiel \& Kahn 2001). Among the serine kinases implicated in this process, $\mathrm{PKC}$ is one candidate with potential 
A
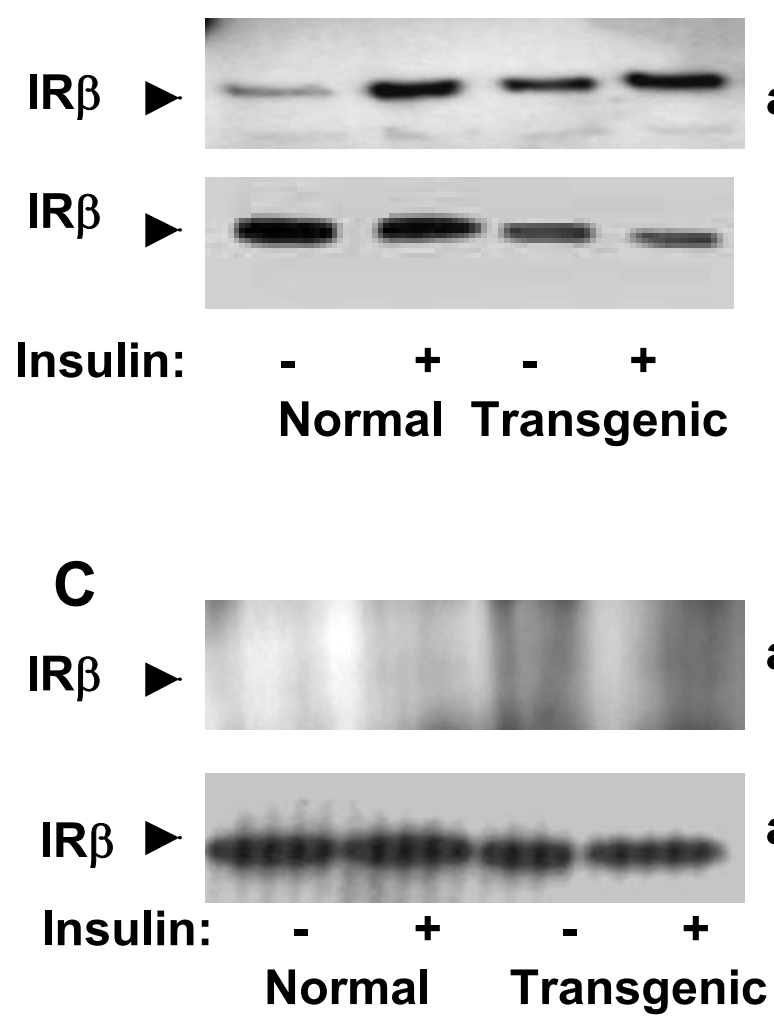

D

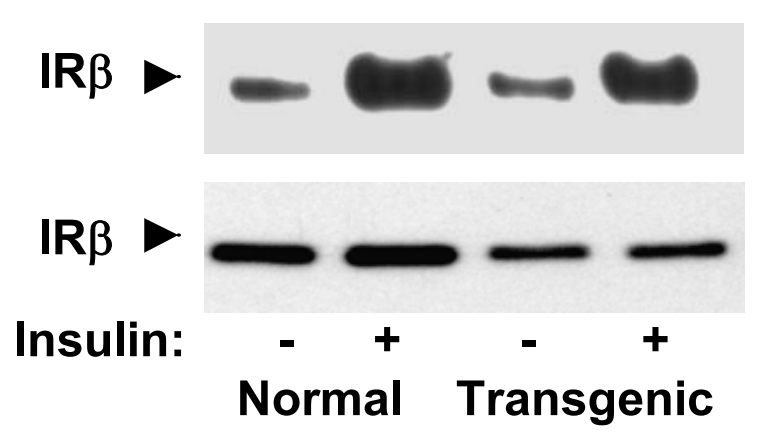

B

\section{anti-PY}

anti-IR

anti-PS994

\section{anti-IR}

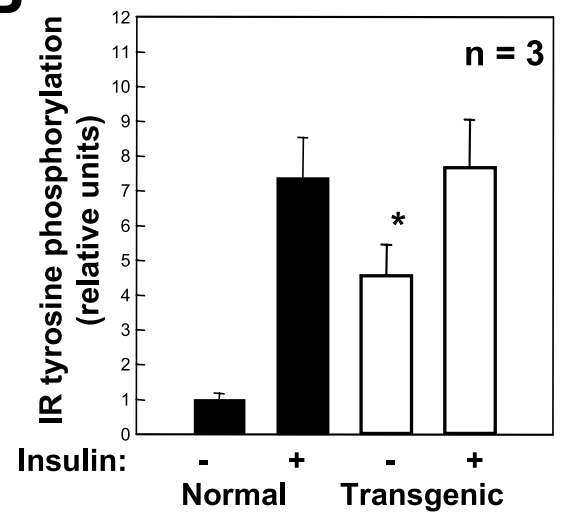

Figure 3 Phosphorylation status of the IR in liver of normal and PEPCK-bGH transgenic mice. Animals were injected with saline (-) or $10 \mathrm{IU}$ insulin (+) per kg/body weight. Equal amounts of solubilized liver proteins obtained as described in Materials and Methods were immunoprecipitated with an anti-IR antibody (anti-IR), separated by SDS-PAGE and immunoblotted either with an anti-phosphotyrosine antibody (anti-PY) (A, upper panel), with anti-PS994 (C, upper panel) or with anti-PT1336 (D, upper panel). Membranes were stripped and reblotted with anti-IR (A, C, and D, lower panels); IR $\beta$, IR $\beta$-subunit. B and $E$, data quantification by densitometric analysis. Values are expressed as relative to control assigning a value of 1 to the mean of saline-injected normal mice. Each bar represents mean \pm S.E.M. of the indicated number of independent experiments. * $P<0.05$ vs saline-injected normal mice. 


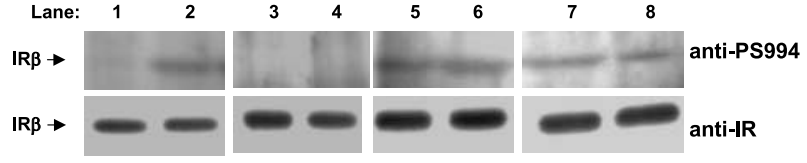

Figure 4 Characterization of the specificity of the PS994 antibody. WGA-purified IRs from obese Zucker rats liver were treated with either active immobilized acid phosphatase (lane 1) or with the immobilized enzyme that had been previously inactivated by boiling for $1 \mathrm{~h}$ (lane 2). After treatment, samples were immunoprecipitated with anti-IR and immunoblotted with anti-PS994. Solubilized extracts from livers of obese Zucker rats were subjected to SDS-PAGE and immunoblotted with anti-PS994 in the presence $(50 \mu \mathrm{g} / \mathrm{ml})$ of the phosphorylated peptide which they were raised against (samples were run in duplicate and are presented in lanes 3 and 4) or the same peptide sequence unphosphorylated (lanes 5 and 6) or with a non-related serine-phosphorylated peptide sequence. (VKTVNE(SP)ASLRERI), (lanes 7 and 8); IR $\beta$, IR $\beta$-subunit.

pathophysiological relevance, since numerous studies have linked excessive PKC activity to diminished insulin sensitivity, especially to that occurring together with increased lipid availability (Considine et al. 1995, Qu et al. 1999, Itani et al. 2000). Such conditions can increase the amount of lipid-signaling molecules derived from free fatty acids that can activate isoforms of the PKC family, such as diacylglycerol or ceramide (Schmitz-Peiffer 2000).

The features of the obese Zucker $(f a / f a)$ rat include insulin resistance, hyperinsulinemia, glucose intolerance, dyslipidemia and impaired insulin signaling in liver and skeletal muscle (Hurrell et al. 1989, Kasiske et al. 1992, Zhou et al. 1999), together with increased PKC activity in insulin target tissues (Considine et al. 1995, Qu et al. 1999), suggesting that this could be a suitable in vivo model to analyze the relationship between IR serine phosphorylation and impaired insulin signaling.

In the present study we have analyzed the status of phosphorylation of Ser 994, a putative inhibitory site of the IR, in liver and skeletal muscle of obese Zucker rats. Phosphorylation of Ser 994 was determined using a

anti-PS994

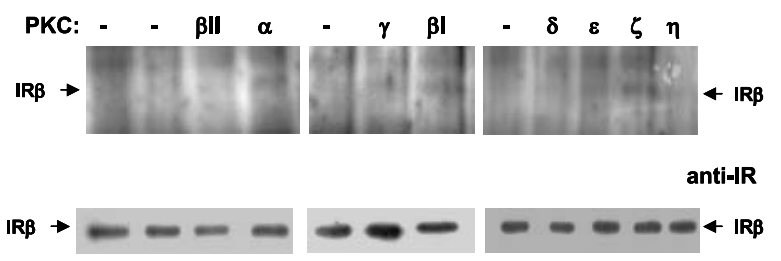

Figure 5 Phosphorylation of IR-Ser 994 by various PKC isoforms. WGA-purified IRs from lean Zucker rats livers were dephosphorylated by incubation with immobilized acid phosphatase and incubated with different PKC isoforms as described in Materials and Methods. Control samples were prepared by incubation in the absence of PKC (-). The resulting samples were immunoprecipitated with anti-IR, separated by SDS-PAGE and immunoblotted with anti-PS994; IR $\beta$, IR $\beta$-subunit. This blot is representative of four different experiments. recently generated anti-phosphopeptide antibody that specifically recognizes IR phosphorylated at this site (Coba et al. 2003). In liver of both lean rats and normal mice, basal IR Ser 994 phosphorylation levels were very low and did not change significantly after in vivo insulin administration, suggesting that phosphorylation at this site may not be modulated by insulin. In contrast, basal phosphorylation levels of IR Ser 994 were found to be markedly elevated in liver of obese Zucker rats. Previous work from Strack et al. demonstrated that insulinstimulated autophosphorylation was increased in mutant human IRs in which serine was exchanged to alanine at position 994, suggesting that this residue plays an inhibitory role on the regulation of the IR kinase (Strack et al. 1997). Based on that result we postulate that excessive phosphorylation of the IR on Ser 994 could have a role in the impairment of the IRK displayed by obese Zucker rats (Karasik et al.1990). Insulin administration resulted in a significant decrease in the phosphorylation levels of IR Ser 994 in liver of obese rats suggesting that activation of the IRK by insulin in vivo might be associated with or might require dephosphorylation of this site.

Phosphorylation levels of Ser 994 were also analyzed in liver of PEPCK-bGH mice, a model of insulin resistance with increased basal IR tyrosine kinase activity (Dominici et al. 1998). In contrast to results obtained in Zucker rats, phosphorylation levels of the IR at Ser 994 were almost not detectable in liver of PEPCK-bGH mice and did not differ from those found in control animals. In a previous study, IRs were purified from liver of PEPCK-bGH mice and treated with immobilized alkaline phosphatase to remove phosphate groups from Ser/Thr residues (Dominici et al. 1998). The in vitro autophosphorylation of the IR was unchanged after this treatment, suggesting that Ser/Thr phosphorylation of the IR $\beta$-subunit was apparently not involved in the regulation of the IRK in these mice (Dominici et al. 1998). Consequently, the current results agree with our previous report in PEPCK-bGH mice (Dominici et al. 1998).

Insulin-induced phosphorylation of the IR at Thr 1336 has been previously demonstrated in cells in culture (Tavare et al. 1991). However, this is the first report to show that IR Thr 1336 is phosphorylated in vivo in an insulin target tissue and that exogenous insulin administration results in an increase of its phosphorylation level. The role of the insulin-stimulated phosphorylation of the IR at Thr 1336 is not clear. Previous in vitro studies demonstrated that this residue of the IR does not participate in the activation or regulation of the IRK (Anderson \& Olefsky 1991, Tavare et al. 1991, Coghlan et al.1994, Kellerer et al. 1995). Possibly, this site could have a regulatory role in the interaction between the IR and intracellular substrates. In liver of obese Zucker rats the phosphorylation level of the IR on Thr 1336 did not correspond with that of Ser 994 and follows the same pattern of phosphorylation observed to tyrosine 
phosphorylation, suggesting that the mechanism of impairment of the IRK in liver of obese Zucker rats does not involve alterations in the phosphorylation of the IR at Thr 1336. Strikingly, the concordance between the phosphorylation of the IR on tyrosine residues and on Thr 1336 that was observed in liver of obese Zucker rats was not observed in liver of PEPCK-bGH mice, where basal IR tyrosine phosphorylation levels were high but those of Thr 1336 were low and similar to those detected in liver of control mice. This result suggests that phosphorylation of the IR at Thr residues could be differentially regulated from phosphorylation at tyrosine residues.

During the last years the involvement of IRSs Ser/Thr phosphorylation in the development of insulin resistance has received increased experimental support. A relationship between a decrease in the insulin-mediated signaling pathway and an increase in the phosphorylation of the IRSs on Ser residues was consistently reported (Sykyotis et al. 2001, Gao et al. 2002, Qiao et al. 2002). Several agents including phorbol esters and free fatty acids are able to induce this phosphorylation (Johnston et al. 2003). Importantly, hyperinsulinemia and TNF- $\alpha$, two inducers of insulin resistance trigger increased Ser/Thr phosphorylation of IRS-1 and IRS-2 (Johnston et al. 2003).

Tumor necrosis factor $\alpha$ activates $\mathrm{PKC} \zeta$ and its downstream effector IkappaB kinase beta (IKK $\beta$ ) (Lallena et al. 1999) a potent inducer of insulin resistance (Kim et al. 2001, Yuan et al. 2001). Protein kinase $C \zeta$ activation leads to a negative control of the insulin-signaling pathway mediated by Ser/Thr phosphorylation of IRS-1 (Liu et al. 2001). Moreover, activation of IKK $\beta$ by TNF- $\alpha$ attenuates insulin signaling and inhibits insulinmediated IRS-1 tyrosine phosphorylation, whereas IKK $\beta$ inhibition by high doses of salicylates prevents Ser/Thr phosphorylation of the IRS proteins (Yuan et al. 2001).

The same inhibitory mechanism that controls the insulin-signaling pathway at the level of the IRS proteins could be involved in the regulation of the IRK. The effects on IRS proteins mediated by salicylates are in part secondary to enhanced IRK activity (Yuan et al. 2001), suggesting that the IKK $\beta$ pathway can negatively regulate both the activity of the IR and the engagement of the IRS proteins in productive insulin signaling. Though there is no direct evidence of a correlation between decreased Ser/Thr phosphorylation of the IRSs and enhanced IRK, the change in the levels of IR Ser/Thr phosphorylation could have a role in the regulation of the IRK.

Among the serine kinases that might be involved in the phosphorylation of the IR on serine residues, $\mathrm{PKC}$ is one candidate with potential pathophysiological relevance. In PKC-mediated insulin-resistant states such as obesity or conditions of elevated lipid availability, both a tissue and isoform-selective PKC activation has been detected (Avignon et al. 1996, Griffin et al. 1999, Cortright et al. 2000). PKC activity is increased in tissues from obese
Zucker rats. In liver this increase appears to be the result of an increase in the membrane content of PKC isoforms $\alpha, \beta, \varepsilon$ and $\zeta$, (Considine et al. 1995, Qu et al. 1999), while in skeletal muscle this increase has been ascribed to an elevation in the membrane content of PKC isoforms $\theta$ (Cortright et al. 2000) and $\varepsilon$ (Avignon et al. 1996). In the current study, we have demonstrated that IR Ser 994 is an in vitro phosphorylation target for PKC. Moreover, by incubating purified IRs with different PKC isoforms, we analyzed the PKC isoform-specificity towards IR Ser 994. Of all the isoforms analyzed, the highest phosphorylation level was attained after incubation with PKC $\zeta$. PKC $\alpha$ and PKC $\beta \mathrm{I}$ were also able to promote phosphorylation at this site but to a lesser extent. In contrast, none of the novel PKC tested $(\delta, \varepsilon, \eta)$ were able to promote phosphorylation of the IR at Ser 994. This tissue and isoform-selective PKC activation might explain the different pattern of phosphorylation observed on Ser 994 in liver and skeletal muscle of obese Zucker rats. Moreover, this suggests that, in muscle of obese Zucker rats, other IR residues could be implicated in the regulation of the IRK.

However, the participation of other serine kinases beside $\mathrm{PKC}$, such as protein kinase A, cannot be ruled out since the latter has been shown to participate in the decreased autophosphorylation that is exhibited by IR from fibroblasts of patients with PCOS (Li et al. 2002). In addition, the Ser/Thr kinases IKK $\beta$ and JNK are implicated in the phosphorylation of the IRS proteins and they could also be involved in the phosphorylation of the IR on Ser/Thr residues (Johnston et al. 2003).

In conclusion, we have demonstrated that Ser 994 and Thr 1336 are in vivo phosphorylation sites of the IR. In addition we have detected a large increase in the phosphorylation of IR Ser 994 in liver of obese Zucker rats under basal conditions that could be involved in the attenuation of the IR kinase displayed by these animals.

\section{Acknowledgements}

D T, F P D and C P are Career Investigators from Consejo Nacional de Investigaciones Cientí ficas y Tecnológicas of Argentina (CONICET). D T received grant support from Fundación Antorchas, the University of Buenos Aires, CONICET and Agencia Nacional de Promoción Cientí fica y Tecnológica of Argentina. AB received support from $\mathrm{NIH}$ through grant AG 19899, and from the Illinois Council on Food and Agricultural Research. The authors wish to thank Dr Matthew Coghlan for kindly providing the anti-phospho Thr 1336 antiserum and Dr Kenneth Siddle for his critical reading of this manuscript.

\section{References}

Al-Hasani H, Eisermann B, Tennagels N, Magg C, Passlack W, Koenen M, Muller-Wieland D, Meyer HE \& Klein HW 1997 
Identification of Ser-1275 and Ser-1309 as autophosphorylation sites of the insulin receptor. FEBS Letters $40065-70$.

Anderson CM \& Olefsky JM 1991 Phorbol ester-mediated protein kinase $\mathrm{C}$ interaction with wild-type and $\mathrm{COOH}$-terminal truncated insulin receptors. Journal of Biological Chemistry 266 21760-21764.

Avignon A, Yamada K, Zhou X, Spencer B, Cardona O, Saba-Siddique S, Galloway L, Standaert ML \& Farese R 1996 Chronic activation of protein kinase $\mathrm{C}$ in soleus muscles and other tissues of insulin-resistant type II diabetic Goto-Kakizaki (GK), obese/aged, and obese/Zucker rats. A mechanism for inhibiting glycogen synthesis. Diabetes 45 1396-1404.

Balbis A, Bartke A \& Turyn D 1996 Overexpression of bovine growth hormone in transgenic mice is associated with changes in hepatic insulin receptors and in their kinase activity. Life Sciences $\mathbf{5 9}$ 1363-1371.

Bollag GE, Roth RA Beaudoin J, Mochly-Rosen D, Koshland \& DE Jr 1986 Protein kinase C directly phosphorylates the insulin receptor in vitro and reduces its protein kinase activity. PNAS $\mathbf{8 3}$ $5822-5824$.

Bossenmaier B, Strack V, Stoyanov B, Krutzfeldt J, Beck A, Lehmann R, Kellerer M, Klein H, Ullrich A, Lammers R \& Häring HU 2000 Serine residues $1177 / 78 / 82$ of the insulin receptor are required for substrate phosphorylation but not autophosphorylation. Diabetes 49 889-895.

Bradford MM 1976 A rapid and sensitive method for the quantitation of microgram quantities of protein utilizing the principle of protein-dye binding. Analytical Biochemistry 72 248-254.

Chin JE, Liu F \& Roth RA 1994 Activation of protein kinase C alpha inhibits insulin-stimulated tyrosine phosphorylation of insulin receptor substrate-1. Molecular Endocrinology 8 51-58.

Coba MP, Turyn D \& Peña C 2003 Synthesis and immunogenic properties of phosphopeptides related to the human insulin receptor. Journal of Peptide Research 61 17-23.

Coghlan MP, Pillay TS, Tavaré JM \& Siddle K 1994 Site-specific anti-phosphopeptide antibodies: use in assessing insulin receptor serine/threonine phosphorylation state and identification of serine-1327 as a novel site of phorbol ester-induced phosphorylation. Biochemical Journal 303 893-899.

Considine RV, Nyce MR, Allen LE, Morales LM, Triester S, Serrano J, Colberg J, Lanza-Jacoby S \& Caro JF 1995 Protein kinase C is increased in the liver of humans and rats with non-insulindependent diabetes mellitus: an alteration not due to hyperglycemia. Journal of Clinical Investigation 95 2938-2944.

Cortright R, Azevedo JL Jr, Zhou Q, Sinha M, Pories WJ, Itani SI \& Dohm GL 2000 Protein kinase C modulates insulin action in human skeletal muscle. American Journal of Physiology 278 E553-E562.

Dominici FP, Balbis A, Bartke A \& Turyn D 1998 Role of hyperinsulinemia on hepatic insulin receptor concentration and autophosphorylation in the presence of high growth hormone levels in transgenic mice overexpressing GH gene. Journal of Endocrinology 159 15-25.

Dunaif A 1997 Insulin resistance and the polycystic ovary syndrome: mechanisms and implications for pathogenesis. Endocrine Reviews $\mathbf{1 8}$ 774-800.

Feener EP, Backer JM, King GL, Wilden PA, Sun XJ, Kahn CR \& White MF 1993 Insulin stimulates serine and tyrosine phosphorylation in the juxtamembrane region of the insulin receptor. Journal of Biological Chemistry 268 11256-11264.

Feener EP, Shiba T, Hu KQ, Wilden PA, White MF \& King GL 1994 Characterization of phorbol ester-stimulated phosphorylation of the human insulin receptor. Biochemical Journal 303 43-50.

Gao Z, Hwang D, Bataille F, Lefevre M, York D, Quon MJ \& Ye J 2002 Serine phosphorylation of insulin receptor substrate 1 by inhibitor B kinase complex. Journal of Biological Chemistry 277 48115-48121.

Griffin ME, Marcucci MJ, Cline GW, Bell K, Barucci N, Lee D, Goodyear LJ, Kraegen EW, White MF \& Shulman GI 1999 Free fatty acid-induced insulin resistance is associated with activation of protein kinase $\mathrm{C}$ theta and alterations of the insulin signaling cascade. Diabetes 48 1270-1274.

Häring HU, Kasuga M, White MF, Crettaz M \& Kahn CR 1984 Phosphorylation and dephosphorylation of the insulin receptor: evidence against an intrinsic phosphatase activity. Biochemistry 23 3298-3306.

Hurrell DG, Pedersen O \& Kahn CR 1989 Alterations in the hepatic insulin receptor kinase in genetic and acquired obesity in rats. Endocrinology 125 2454-2462.

Itani SI, Zhou Q, Pories WJ, MacDonald KG \& Dohm GL 2000 Involvement of protein kinase $\mathrm{C}$ in human skeletal muscle insulin resistance and obesity. Diabetes 49 1353-1358.

Johnston AM, Pirola L \& Van Obberghen E 2003 Molecular mechanisms of insulin receptor substrate protein-mediated modulation of insulin signaling. FEBS Letters 546 32-36.

Karasik A, Rothenberg PL, Yamada K, White MF \& Kahn CR 1990 Increased protein kinase activity is linked to reduced insulin receptor autophosphorylation in liver of starved rats. Journal of Biological Chemistry 265 10226-10231.

Kasiske BL, O’Donnell MP \& Keane WF 1992 The Zucker rat model of obesity, insulin resistance, hyperlipidemia, and renal injury. Hypertension 19 (Suppl 1) 110-115.

Kasuga M, Zick Y, Blith DL, Karlsson FA, Häring HU \& Kahn CR 1982 Insulin stimulation of phosphorylation of the beta subunit of the insulin receptor. Formation of both phosphoserine and phosphotyrosine. Journal of Biological Chemistry 257 9891-9894.

Kellerer M, Coghlan MP, Capp E, Mühlhöler A, Kroder G, Mosthaf L, Galante P, Siddle K \& Häring HU 1995 Mechanism of insulin receptor kinase inhibition in non- insulin-dependent diabetes patients. Phosphorylation of serine 1327 or threonine 1348 is unaltered. Journal of Clinical Investigation 96 6-11.

Kim JK, Kim YJ, Fillmore JJ, Chen Y, Moore I, Lee J, Yuan M, Li ZW, Karin M, Perret P, Shoelson SE \& Shulman GI 2001 Prevention of fat-induced insulin resistance by salicylate. Journal of Clinical Investigation 108 437-446.

Kuroki T, LeRoith D \& Zick Y 2001 Insulin stimulates PKCzeta-mediated phosphorylation of insulin receptor substrate-1 (IRS-1). A self-attenuated mechanism to negatively regulate the function of IRS proteins. Journal of Biological Chemistry 276 14459-14465.

Lallena MJ, Diaz-Meco MT, Bren G, Paya CV \& Moscat J 1999 Activation of IkappaB kinase beta by protein kinase $\mathrm{C}$ isoforms. Molecular and Cellular Biology 19 2180-2188.

Lewis RE, Wu GP, MacDonald RG \& Czech MP 1990a Insulin-sensitive phosphorylation of serine 1293/1294 on the human insulin receptor by a tightly associated serine kinase. Journal of Biological Chemistry 265 947-954

Lewis RE, Cao L, Perregaux D \& Czech MP $1990 b$ Threonine 1336 of the human insulin receptor is a major target for phosphorylation by protein kinase C. Biochemistry 29 1807-1813.

Li M, Youngren JF, Dunaif A, Goldfine ID, Maddux BA, Zhang BB \& Evans JL 2002 Decreased insulin receptor (IR) autophosphorylation in fibroblasts from patients with PCOS: effects of serine kinase inhibitors and IR activators. Journal of Clinical Endocrinology and Metabolism 87 4088-4093.

Liu F \& Roth RA 1994a Identification of serines-967/968 in the juxtamembrane region of the insulin receptor as insulin-stimulated phosphorylation sites. Biochemical Journal 298 471-477.

Liu F \& Roth RA $1994 b$ Identification of serines-1035/1037 in the kinase domain of the insulin receptor as protein kinase $\mathrm{C}$ alpha mediated phosphorylation sites. FEBS Letters 352 389-392.

Liu YZ, Paz K, Herschkovitz A, Alt A, Tennenbaum T, Sampson SR, Ohba M, Kuroki T, LeRoith D \& Zick Y 2001 Insulin stimulates PKC zeta-mediated phosphorylation of insulin receptor substrate-1 (IRS-1). A self-attenuated mechanism to negatively regulate the function of IRS proteins. Journal of Biological Chemistry 276 14459-14465. 
Pillay TS, Whittaker J, Lammers R, Ullrich A \& Siddle K 1991 Multisite serine phosphorylation of the insulin and IGF-1 receptors in transfected cells. FEBS Letters 288 206-211.

Qu X, Seale JP, Donnelly R 1999 Tissue and isoform-selective activation of protein kinase $\mathrm{C}$ in insulin resistant obese Zucker rats - effects of feeding. Journal of Endocrinology 162 207-214.

Saltiel AR \& Kahn CR 2001 Insulin signaling and the regulation of glucose and lipid metabolism. Nature 414 799-806.

Schmitz-Peiffer C 2000 Signalling aspects of insulin resistance in skeletal muscle: mechanisms induced by lipid oversupply. Cell Signal 12 583-594.

Shao J, Catalano PM, Yamashita H, Ruyter I, Smith S, Youngren J \& Friedman JE 2000 Decreased insulin receptor tyrosine kinase activity and plasma cell membrane glycoprotein-1 overexpression in skeletal muscle from obese women with gestational diabetes mellitus (GDM): evidence for increased serine/threonine phosphorylation in pregnancy and GDM. Diabetes 49 603-610.

Stadtmauer L \& Rosen OM 1986 Increasing the cAMP content of IM-9 cells alters the phosphorylation state and protein kinase activity of the insulin receptor. Journal of Biological Chemistry 261 3402-3407.

Strack V, Stoyanov B, Bossenmaier B, Mosthaf L, Kellerer M \& Haring HU 1997 Impact of mutations at different serine residues on the tyrosine kinase activity of the insulin receptor. Biochemical and Biophysical Research Communications 239 235-239.

Strack V, Hennige AM, Krützfeldt J, Bossenmaier B, Klein HH, Kellerer M, Lammers R \& Haring HU 2000 Serine residues 994 and $1023 / 25$ are important for insulin receptor kinase inhibition by protein kinase C isoforms beta2 and theta. Diabetologia 43 443-449.

Sykiotis GP \& Papavassiliou AG 2001 Serine phosphorylation of insulin receptor substrate-1: A novel target for the reversal of insulin resistance. Molecular Endocrinology 15 1864-1869.

Takayama S, White MF, Lauris V \& Kahn CR 1984 Phorbol esters modulate insulin receptor phosphorylation and insulin action in cultured hepatoma cells. PNAS 81 7797-7801.
Takayama S, White MF \& Kahn CR 1988 Phorbol ester-induced serine phosphorylation of the insulin receptor decreases its tyrosine kinase activity. Journal of Biological Chemistry 263 3440-3447.

Tavare JM, Zhang B, Ellis L \& Roth R 1991 Insulin-stimulated serine and threonine phosphorylation of the human insulin receptor. An assessment of the role of serines 1305/1306 and threonine 1348 by their replacement with neutral or negatively charged amino acids. Journal of Biological Chemistry 266 21804-21809.

Ullrich A, Bell JR, Chen, EY, Herrera R, Petruzzelli LM, Dull TJ, Gray A, Coussens L, Liao YC, Tsubokawa M, Mason A, Seeburg PH, Grundfeld C, Rosen OM \& Ramachandran J 1985 Human insulin receptor and its relationship to the tyrosine kinase family of oncogenes. Nature 313 756-761.

Valera A, Rodriguez-Gil, JE, Yun JS, McGrane, MM, Hanson RW \& Bosch F 1993 Glucose metabolism in transgenic mice containing a chimeric P-enolpyruvate carboxykinase/bovine growth hormone gene. FASEB Journal 7 791-800.

White MF \& Kahn CR 1994 The insulin signalling system. Journal of Biological Chemistry 269 1-4.

Yuan M, Konstantopoulos N, Lee J, Hansen L, Li ZW, Karim M \& Shoelson SE 2001 Reversal of obesity- and diet-induced insulin resistance with salicylates or targeted disruption of Ikkbeta. Science $2931673-1677$.

Zhou Q, Dolan PL \& Dohm GL 1999 Dephosphorylation increases insulin-stimulated receptor kinase activity in skeletal muscle of obese Zucker rats. Molecular and Cellular Biochemistry 194 209-216.

Received in final form 16 April 2004

Accepted 11 June 2004

Made available online as an

Accepted Preprint 28 June 2004 